\title{
MEDIA SOSIAL DAN LITERASI KEBENCANAAN DI BALI
}

\author{
Ni Made Ras Amanda Gelgel \\ rasamanda13@unud.ac.id \\ Ilmu Komunikasi, Universitas Udayana
}

\section{Article Info}

Keyword:

Bali, Disaster, Mt. Agung, Literacy, Social Media,

\begin{abstract}
After a large, deadly explosive and effusive eruption during 1963-64, Indonesia's Mount Agung on Bali remained quiet until a new eruption began in November 2017 until 2019. Alert Level III (of four levels) remained in effect throughout the period with a $4 \mathrm{~km}$ exclusion radius around the volcano. Massive hysteria occurred when alert level reach the highest level (level IV). The situation get worsed when misinformation has been spreading in social media about Mt. Agung. This research discussing how literate was the Balinese in consuming disaster information. The research was in 2018 used positivisim paradigm. Data collected by using questionnaire with 410 sample from all the regency in Bali Province. Main theory was dependence theory. The result are (1) social media became the most sourceful media to gain disaster information, (2) but the Balinese people didn't verify the information they gained (3) 30 percent respondent shared the information without verification. It showed Balinese's literacy in gaining disaster information need to be improve and have a high dependence in using social media.
\end{abstract}

Copyright (C) 2020 Interaksi: Jurnal Ilmu Komunikasi. All rights reserved.

\section{PENDAHULUAN}

Indonesia secara geografis merupakan Negara dengan wilayah yang penuh ancaman bencana alam, mulai dari gempa bumi hingga tsunami. Catatan Direktorat Vulkanologi dan Mitigasi Bencana Geologi (DVMBG) Departemen Energi dan Sumber Daya Mineral menunjukan bahwa ada 28 wilayah di Indonesia yang dinyatakan rawan gempa dan tsunami. Di antaranya Nanggroe Aceh Darussalam, Sumatra Utara, Sumatra Barat, Bengkulu, Lampung, Banten, Jateng dan Daerah Istimewa Yogyakarta bagian selatan, Jawa Timur bagian selatan, Bali, Nusa Tenggara Barat dan Nusa Tenggara Timur, kemudian Sulawesi Utara, Sulawesi Tengah, Sulawesi Selatan, Maluku Utara, Maluku Selatan, Biak, Yapen dan Fak-Fak di Papua serta Balikpapan Kalimantan Timur.

Indonesia merupakan bagian dari jalur The Pasific Ring of Fire (Cincin Api Pasifik) (BPN.go.id, 2019), yang merupakan jalur rangkaian gunung api aktif di dunia. Indonesia memiliki gunung berapi dengan jumlah kurang lebih 240 buah, hampir 70 di antaranya masih aktif. Salah satu di antaranya adalah Gunung Agung di Pulau Bali. Gunung Agung adalah gunung tertinggi di Pulau Bali, yang berada di Kecamatan Rendang, Kabupaten Karangasem, Bali. Berdasarkan catatan, Gunung Agung meletus pertama kali pada 1808. Namun letusan terbesar adalah pada tahun 1963. Letusan ini berlangsung hingga awal tahun 1964, dengan jumlah korban meninggal dunia mencapai 1148 orang, dan ratusan lainnya luka-luka.

Setelah tidur lama, akhir tahun 2017 hingga pertengahan Tahun 2019, Gunung Agung kembali menunjukkan aktivitasnya. Status gunung agung naik menjadi waspada, siaga kemudian awas, ribuan warga dievakuasi. Aktivitas yang terjadi beragam yakni dari semburan abu vulkanik, letusan fratik, gempa bumi, kebakaran hutan di lereng Gunung hingga lontaran batu pijar dari kawah. Hingga 2018 Gunung Agung mengeluarkan kolom abu dengan ketinggian yang beragam (Kompas.com, 2018).

Kepanikan terbesar yang terjadi pada masa aktifnya Gunung Agung adalah pada saat penetapan status awas, di akhir November 2017. Peningkatan status yang 
dilakukan menjelang malam hari menyebabkan arus pengungsi yang tidak terkendali. Kabar kepanikan ini diperparah dengan banyaknya misnformasi mengenai bencana gunung api khususnya Gunung Agung. Haddow (2008) mengungkapkan komunikasi adalah kunci sukses dari seluruh proses bencana, mulai dari mitigasi, persiapan, respons dan pemulihan kembali. Perencanaan dan kontrol arus komunikasi sebelum, selama dan setelah bencana akan berpengaruh pada pengelolaan bencana itu sendiri.

Di masa era informasi ini, media baru memberi tantangan baru dalam proses komunikasi bencana. Di Indonesia, aplikasi percakapan whatsapp adalah aplikasi terpopuler, menurut laporan comScore (2017), whatsapp memiliki sekitar 35,8 juta pengguna di Indonesia. Trisnani (2019) menuliskan penggunaan whatsapp dianggap paling efektif dan terpercaya untuk komunikasi. Aplikasi ini banyak digunakan untuk kepentingan sosialisasi, berbagi informasi, dan penyampai pesan yang bersifat individu, kelompok, organisasi dan komunitas. Fitur kamera di telepon seluler terutama pada smartphone memudahkan seseorang mengirimkan pesan gambar via whatsapp atau media sosial lainnya. Hal ini membuat siapapun dapat menjadi komunikator pertama yang melaporkan langsung keadaan setempat. Peran pemerintah pada komunikasi bencana sebagai gate keeper informasi akhirnya tergantikan sejalan dengan meningkatnya penggunaan dan pengaruh dari media terbarukan ini. Namun prinsipprinsip dasar dari komunikasi bencana yang efektif tetap tidak berubah yakni transparansi, terbukanya akses, kepercayaan dan reliabilitas serta bekerjasama dengan media.

Kasus kepanikan akibat misinformasi ini adalah contoh dampak dari rendahnya literasi media digital bagi masyarakat khususnya di Bali. Masyarakat seakanakan gagap mendapatkan informasi melalui media sosial. Rudianto (2015) menekankan dalam komunikasi kebencanaan, masyarakat tidak hanya cukup diberikan informasi yang berlimpah. Hal yang menjadi perhatian adalah bagaimana cara memproses dan menyampaikan informasi kepada masyarakat. Proses ini menjadi penting karena apabila terjadi kekeliruan penyampaian informasi kebencanaan maka aman menimbulkan ketidakpastian yang aman memperburuk situasi. Maka tuli- san ini mengangkat diskusi dan hasil penelitian yang menggambarkan bagaimana masyarakat di Bali menggunakan media sosial dalam mengolah dan menerima informasi kebencanaan. Tulisan ini bertujuan untuk memberi gambaran literasi digital masyarakat dalam konteks kebencanaan. Dengan data yang disajikan dan diolah akan dapat memberi masukan kepada pemerintah dan kelompok-kelompok masyarakat untuk meningkat kesiapsiagaan sistem komunikasi kebencanaan.

\section{KAJIAN PUSTAKA}

\section{Metodologi}

Penelitian ini adalah penelitian dengan pendekatan dan paradigma positivisime/objektifitas. Kriyantono (2014:50-51) menyebutkan bahwa realitas yang terjadi di masyarakat dapat diukur dengan standar tertentu, digeneralisasi dan bebas dari konteks dan waktu. Penelitian ini adalah penelitian deskriptif kuantitatif dengan pengumpulan data menggunakan kuesioner. Kuesioner disebarkan pada bulan Agustus 2018 kepada 410 responden di seluruh Kabupaten di Provinsi Bali. Teknik penentuan sampel adalah acak dengan ketentuan responden terpilih memiliki smartphone dengan akses internet. Penelitian bersifat deskriptif dengan penyajian data menggunakan analisis data distribusi frekuensi dan tabulasi silang.

Penelitian ini menggunakan statistik inferensia atau parameter. Martono (2010:5-6) menyebutkan parameter adalah nilai yang menggambarkan ciri/ karakteristik populasi, atau suatu nilai yang stabil karena nilai tersebut diperoleh dari hasil observasi seluruh anggota populasi dengan menggunakan sampel populasi. Statistika yang digunakan adalah statistik non parametris di mana statistik ini menganalisis data yang berskala nominal atau ordinal dari populasi yang bebas distribusi. Jadi penelitian ini menggunakan skala nominal dan ordinal tidak mengukur hingga skala atau tingkat interval maupun rasio.

Penyajian data akan diuraikan dengan grafik berdasarkan olah data distribusi frekuensi. Martono (2010:37-38) menyebutkan distribusi frekuensi adalah proses penyusunan data dari nilai terendah hingga terbesar atau sebaliknya. Tabel distribusi frekuensi 
memudahkan penyajian data sehingga mudah dipahami dan dibaca sebagai bahan informasi, kemudian dapat digunakan dalam perhitungan membuat gambar statistik dalam berbagai bentuk penyajian data.

\section{Kajian Konseptual}

\section{Komunikasi Bencana}

United Nation's Interational Strategy for Disaster Reduction (UNISDR 2000) menyebutkan bencana adalah gangguan serius atas keberfungsian masyarakat yang menimbulkan kerugian yang meluas pada kehidupan manusia dari segi materi, ekonomi atau lingkungan dan gangguan itu melampaui kemampuan masyarakat yang bersangkutan. UU Nomor 24/2007 tentang Penanggulangan Bencana mendefinisikan konsep penanggulangan bencana sebagai peristiwa atau rangkaian peristiwa yang mengancam dan menganggu kehidupan dan penghidupan masyarakat yang disebabkan faktor alam, non alam atau manusia, sehingga menyebabkan timbulnya korban jiwa, kerusakan lingkungan, kerugian harta benda dan dampak psikologis. Jenis bencana berdasarkan UU dibagi tiga yakni bencana alam, bencana non alam dan bencana sosial. Bencana yang tergolong bencana alam adalah gempa bumi, tsunami, gunung meletus, banjir, kekeringan, angina topan, tanah longsor. Bencana non-alam adalah gagal teknologi, gagal modernisasi, epidemi, wabah penyakit. Bencana sosial adalah konflik sosial antarkelompok atau antar-komunitas masyarakat dan terror. Purwo Nugroho (2018:75-77) menyebutkan Badan Nasional Penanggulangan Bencana mencatat selama sepuluh tahun terakhir (2008-2018) bencana di Indonesia masih didominasi oleh banjir, longsor dan puting beliung

Berdasarkan UU no 24/2007 tentang penanggulangan bencana, asas dan pinsip penanggulangan bencana adalah selain berdasar pada ilmu pengetahuan dan teknologi adalah bersifat professional. Purwo Nugroho (2018:96-97) menyebutkan penanggulangan bencana sebaiknya dilakukan dengan tepat serta cepat sesuai tuntutan keadaan. Oleh karena itu maka komunikasi bencana menjadi sesuatu yang penting dilakukan

Haddow (2008:xvii) membagi tahap manajemen komunikasi bencana menjadi 4 tahapan. Di setiap taha- pan diperlukan strategi komunikasi yang menyediakan informasi secara periodik dan akurat. Empat tahapan tersebut adalah (1)mitigasi, mempromosikan dan mengimplementasikan strategi, teknologi dan aksi yang diharapkan akan mengurangi korbanjiwa dan kerusakan apabila terjadi bencana; (2) preparednesspersiapan, untuk mengkomunikasikan pesan-pesan yang mendukung dan mendidik masyarakat dalam antisipasi bencana; (3) respon, menyediakan notifikasi kepada masyarakat, peringatan, evakuasi dan perkembangan situasi saat terjadi bencana; (4) recovery atau pemulihan, membantu individu dan komunitas yang terdampak bencana pascabencana. Dasar efektifitas strategi komunikasi bencana yakni pada lima asumsi penting yakni, customer focus, leadership commitment, inclusion of communications in planning, situational awareness dan media partnership.

Budi HH (2012) memaparkan bahwa komunikasi adalah salah satu aspek yang sering menjadi persoalan dalam manajemen bencana. Faktor-faktor lain yang menjadi persoalan selain komunikasi adalah informasi, koordinasi dan kerjasama. Haddow (2008, dalam Budi HH, 2012:371) menjelaskan khalayak adalah fokus penting dalam sebuah komunikasi bencana. Pemahaman akan karakteristik khalayak mempengaruhi bagaimana pesan diterima oleh khalayak tersebut dan agar pesan mitigasi bencana menjadi efektif. Aspek lain yang perlu diperhatikan adalah aspek komitmen kepemimpinan lembaga-lembaga terkait agar tidak terjadi tumpang tindih informasi dan kewenangan. Aspek terakhir yang perlu diperhatikan adalah media Haddow menekankan pentingnya peran media dalam sebuah peristiwa bencana. Media memiliki dua peran, positif dalam hal mengedukasi masyarakat namun media diharapkan tidak menjadikan bencana sebagai komoditas.

Purwo Nugroho (2018:125) menuliskan bahwa kajian mengenai komunikasi bencana pada umumnya membahas mengenai hal-hal khusus saja seperti bagaimana menyampaikan sebuah informasi bencana, bagaimana mengatur media massa sebagai salah satu elemen penanggulangan bencana dan mengatur koordinasi komunikasi antar kelompok dan penggiat kemanusiaan dan lembaga penanggulangan bencana agar 
koordinasi berjalan optimal.

\section{Media Baru dan Bencana}

Haddow (2014:25) menyatakan bahwa media sosial adalah alat, teknologi dan aplikasi berbasis internet yang memungkinan terjadinya komunikasi interaktif dan pertukaran konten antara para pengguna yang perannya fleksibel baik sebagai pengirim maupun penerima pesan sebagai komponen utama dalam media sosial Internet dan media sosial telah merubah bagaimana berita dikemas dan didistribusikan. Haddow (2008:36) menuliskan kemajuan teknologi ini pun merubah alur dan arus informasi, menghilangkan peran gatekeepers, merubah alur komunikasi top-down yang digunakan pmerintah dan media, serta memberdayakan masyarakat dalam membentuk jaringan komunikasi yang bersifat ad hoc. Gillmor (2006) juga menyatakan bahwa kemajuan teknologi informasi seperti internet ini membuat siapapun dapat menjadi sumber penyebar informasi. Bowman (2003 dalam Haddow, 2008: 37) juga menambahkan, siapa pun dapat menjadi jurnalis dan hegemoni gatekeeper akan terancam dengan perubahan peran dari khalayak itu sendiri. Saat khalayak pasif menjadi khalayak yang aktif dalam membuat berita dan menyebarkannya maka alur informasi tidak dapat lagi dikontrol oleh jurnalis maupun agen-agen pemerintah. Informasi yang tersaji untuk masyarakat saat terjadi krisis biasanya tidak memadai, bias atau terlambat. Gillmor dan Hattotuwa (2007, dalam Haddow, 2008:38) menyatakan bahwa permasalahan terbesar tidak berada pada penggunaan teknologi tetapi pada budaya penyebaran atau sharing informasi di masyarakat.

R. Yudha (2017) dalam jurnalnya menuliskan bahwa peristiwa-peristiwa atau kasus yang kemudian viral kasus di media sosial berpengaruh secara massif dan dianggap sebagai sebuah kebenaran. Publik kemudian menganggap hal tersebut adalah kebenaran dan turut membagikannya sehingga semakin popular. Ironisnya penyebar pesan atau pengunggah tidak menyadari dampak dari perbuatan ini.

Glaser (2006, dalam Haddow 2014) menyatakan bahwa paradigma komunikasi penyiaran mengenai penyiaran dari satu sumber ke pesan telah tidak berlaku. Komunikasi sekarang adalah percakapan antara banyak sumber, di mana semua orang dapat berperan sebagai pembuat pesan, penerima pesan, pencipta isi pesan dan kurator. Mark Glaser (2006) menyatakan bahwa khalayak mengetahui lebih banyak melalui sistem kolektif dibandingkan para jurnalis. R. Yudha (2017) menyatakan bahwa pesan yang tersebar di media sosial melahirkan interpretasi yang berbeda-beda oleh penerima pesan tersebut. Dampak yang ditimbulkan pun beragam tergantung pada banyak hal. Pesan di media sosial dapat berupa pesan verbal maupun non verbal. Parabahasa dalam Bahasa nonverbal ini memiliki kemampuan untuk menggugah emosi lawan bicara. Interpretasi pesan ini kemudian dipahami sesuai tingkat pemahamannya masing-masing.

Studi Brenner (2013) di Amerika Serikat mengungkap masyarakat kini dapat dengan mudah mengakses, membuat, mempengaruhi atau membagi berita di manapun dan kapan pun. Hal ini didorong dengan semakin meningkatknya media sosial berbasis internet seperti twitter dan facebook yang berperan sebagai penyedia berita. Fenomena ini pun didorong dengan meningkatnya pengguna smartphone sehingga memiliki akses langsung terhadap internet. Tercatat 81 persen usia dewasa memiliki akses internet melalui smartphone mereka di Amerika Serikat. Hal ini menurut Pew (2019) membuat hubungan khalayak dengan berita menjadi portable, personalized dan participatory. Namun hal ini tidak menurunkan minat khalayak untuk memperoleh informasi maupun berita. Bahkan saat ini khalayak mendapatkan informasi yang lebih banyak dibandingkan sebelumnya. Penurunan terjadi pada penggunaan sumber-sumber berita konvensional, namun khalayak mulai tergantung pada media sosial dan internet sebagai sumber informasi. Peningkatan sumber informasi dari media sosial ini semakin meningkat drastis.

Asteria (2016) menyebutkan Informasi yang tersebar melalui media sosial maupun yang digagas oleh jurnalisme warga dalam keadaan bencana dapat menjadi jembatan bagi khayalak untuk mengetahui informasi tanpa batasan dan dukungan pada media komunitas untuk melengkapi informasi yang diterima khalayak melalui internet.

N. Fithryani (2015) dalam tulisannya yang ber- 
judul "Peran Citizen Journalism dalam Program Berita Stasiun Televisi (Studi Deskriptif Kualitatif pada Situs Liputan6.com pada Program Berita Liputan6 SCTV", menekankan kekhawatirannya mengenai nilai objektivitas dan kredibilitas dari jurnalisme warga di jurnalisme online. Jurnalisme seperti ini berkembang pesat ini dan bersifat real time, di mana semua pihak dapat mengirimkan pesan tanpa ada proses gatekeeping atau penyeleksian. N. Fithryani (2015) menjelaskan dalam media online, aspek yang menjadi prioritas adalah kecepatan bukan faktualitas. Hal ini berbeda dengan media massa lainnya seperti Koran, buku, televisi yang melalui proses verifikasi sebelum informasi itu tersebar. Jurnalisme ini pun dinilai seringkali berdasarkan isu dengan narasumber yang tidak jelas dan kebenaran atas fakta yang ditulis kerap dipertanyakan. Ironisnya N. Fithryani (2015) menyebutkan sistem seperti ini kerap merugikan beberapa pihak karena ketidakjelasan kebenaran dan tidak melaksanakan praktik jurnalisme yang baik seperti cover both sides.

Peran jurnalistik dalam meliput bencana menjadi hal yang penting. Arif (2010) mengatakan dalam meliput bencana, jurnalis kadang menulis berita tanpa mengedepankan keseimbangan maupun memverifikasi ulang sebuah fakta yang didapatkan. Akibat dari keteledoran ini, maka jurnalis termakan dan menjadi penyebar berita bohong atau hoax, sehingga menjadi bencana tersendiri. Pemberitaan mengenai bencana Gunung Agung menurut Panuju (2018) di balipost.com cenderung memenuhi kaidah jurnalistik dan kaidah jurnalistik bencana. Namun Panuju (2018) menekankan kurangnya tulisan mendalam yang disajikan media balipost.com dan kurangnya penulisan yang berdasarkan observasi.

\section{Teori Dependensi Media}

Littlejohn dan Foss (2009 :979-980) menjelaskan dalam menggunakan media, pengguna kerap kali mengembangkan ketergantungan yang akhirnya memperkuat kekuatan media akan masyarakat penggunanya. Pengaruhnya berkembang pada tingkat kognitif, afektif bahkan perilaku. Sandra Ball-Rokeach dan Melvin DeFleur (1970, dalam Littlejohn, 2009: 980) memandang audiens, media dan sistem sosial bekerja bersamaan. Tingkat dependensi atau ketergantungan indi- vidu terhadap media dipengaruhi tingkat kebutuhan individu, motif, kondisi sosial dan tujuan kehidupan. Contohnya apabila individu yang membutuhkan banyak informasi maka akan mengekspose media dengan cukup tinggi. Dalam teori dependensi terdapat alternatif fungsional. Hal ini bicara tentang alternatif-alternatif media yang digunakan dalam menjadi informasi. Apabila media lain tidak dapat digunakan atau tidak memberikan informasi yang cukup maka ketergantungan terhadap media tertentu akan semakin tinggi. Alternatif media juga mampu membuat seseorang tidak tergantung pada salah satu media saja. Para peneliti efek media menggunakan teori dependensi untuk melihat bagaimana ragam pola dampak eksposure media. Mereka yang menggunakan beragam alternatif media akan lebih memiliki pengetahuan, keluasan informasi dan pemahaman yang mendalam akan suatu isu dibanding mereka yang hanya menggunakan satu media.

\section{TEMUAN DAN DISKUSI}

\section{Gambaran Umum Responden}

Responden berasal dari berbagai kabupaten di Provinsi Bali, dengan total 410 responden. Dari total $100 \%$ responden yang tersebar di seluruh Bali, responden terbanyak berada di dua kabupaten, yakni Kabupaten Tabanan sebanyak 20,5\% dan Kabupaten Buleleng sebanyak 20,5\%. Jumlah responden terbesar kedua yaitu Kabupaten Jembrana dengan jumlah responden sebanyak 17,6\%, mengikuti yakni responden Kabupaten Karangasem sebanyak 15,1\%, responden Kabupaten Klungkung sebanyak 8,8\%, responden Kabupaten Gianyar sebanyak 5,9\%, dan responden Kabupaten Bangli sebanyak 2,9\%. Dari keseluruhan responden, sebagian besar menjawab pernah menerima informasi terkait kebencanaan khususnya informasi mengenai status atau kondisi terkini Gunung Agung.

Berdasarkan jenis kelamin, 43\% responden perempuan dan $57 \%$ responden laki-laki. Dalam penelitian kali ini, peneliti membagi responden ke dalam lima kategori, yaitu petani/pedagang, wirausaha/ swasta, PNS/dosen/dosen, pelajar dan pensiunan. Dalam pengambilan data, kategori tersebut mendapatkan jumlah responden yang berbeda. Responden petani/ pedagang sebanyak $29 \%$, responden wiraswata/swasta 
sebanyak $26 \%$, responden pelajar sebanyak $31 \%$, responden PNS/guru/dosen sebanyak $12 \%$, dan responden pensiunan hanya sebanyak $2 \%$ dari seluruh responden.

Kategori pendidikan terakhir responden yang terbagi dalam beberapa kategori yakni kategori tidak sekolah, Pendidikan terakhir SD/SMP, SMA, S1, S2, dan S3. Masing-masing kategori memiliki jumlah responden yang beragam. Jumlah terbanyak yakni responden yang memiliki pendidikan terakhir yaitu SMA sebanyak 50\%. Jumlah responden terendah memiliki pendidikan terakhir yaitu S3 dengan jumlah sebanyak $0 \%$. Hal ini menunjukkan bahwa rata-rata responden memiliki latar belakang Pendidikan minimal SMA atau Pendidikan Menengah.

\section{Masyarakat Bali dan Media Baru}

Pada penelitian kali ini, kepemilikan media sosial dan surat elektronik dibagi dalam enam jenis media sosial dan elektronik yang masih digunakan oleh sebagian besar masyarakat Indonesia. Enam jenis media sosial tersebut adalah facebook, instagram, whatsapp, $B B M$, e-mail, dan line. Masing-masing jenis media sosial tersebut memiliki jumlah pengguna yang beragam. Secara garis besar, sebanyak $68 \%$ responden merupakan pengguna whatsapp. Kemudian menyusul facebook dan e-mail yang masing-masing memiliki responden sebanyak $64 \%$, kemudian $51 \%$ responden merupakan pengguna instagram, dan $48 \%$ responden menggunakan pengguna line. Jumlah terrendah ialah responden yang merupakan pengguna $B B M$ dengan persentase hanya $22 \%$. $B B M$ menjadi platform bermedia sosial yang memiliki pengguna paling sedikit di antara para responden. Hal ini terlihat pada diagram 1. Kepemilikan Media.

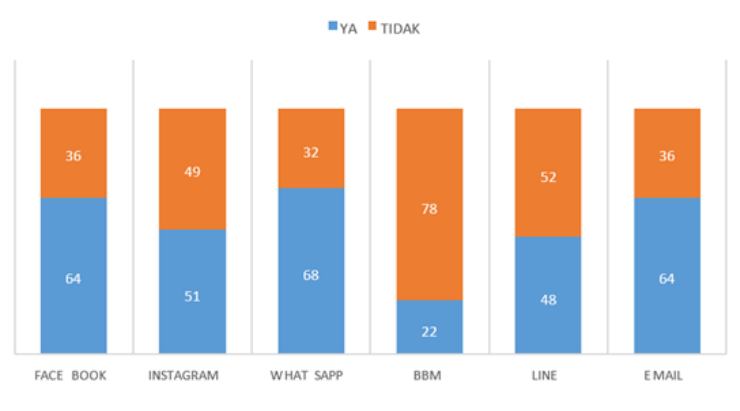

Diagram 1.

Kepemilikan Media

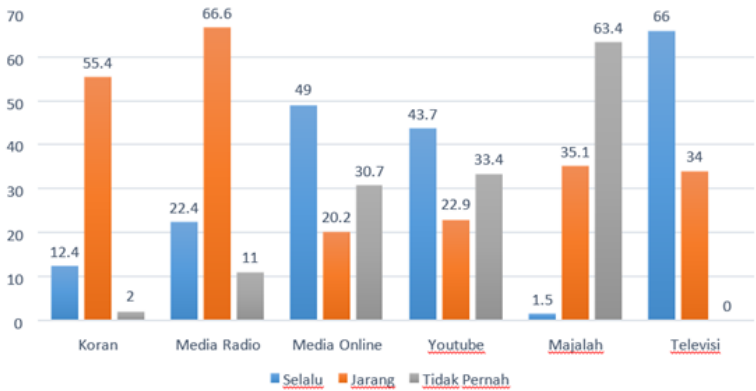

Diagram 2.

Frekuensi Konsumsi Media per Minggu

Pada diagram 2 memperlihatkan frekuensi responden dalam menggunakan media sosial dan media massa. Dalam penelitian kali ini, peneliti mengukur frekuensi penggunaan media di berbagai jenis media yang dikonsumsi oleh responden dalam satu minggu. Media-media tersebut di antaranya adalah Koran, media radio, media online, youtube, majalah dan televisi. Hasil yang didapatkan cukup beragam dari masingmasing jenis media. Secara garis besar, televisi, youtube dan media online memiliki jumlah presentasi yang cukup tinggi sebagai media yang sering dikonsumsi oleh responden dalam satu minggu. Dengan rincian sebagai berikut: televisi sebanyak $66 \%$ responden, media online sebanyak $49 \%$ responden dan youtube sebanyak 43,7\% responden sebagai media yang selalu dikonsumsi setiap minggunya.

Sementara itu, media radio dan Koran merupakan media yang cukup jarang dikonsumsi oleh responden. Hal ini ditunjukkan dari data yang peneliti dapatkan bahwa sebanyak $66,6 \%$ responden mengaku jarang menggunakan radio sebagai media informasi, dan sebanyak 55,4\% responden mengaku jarang membaca Koran sebagai sarana informasi secara mingguan. Sebagian besar responden tidak pernah menggunakan majalah sebagai sarana informasi mingguannya. Sebanyak $63,4 \%$ responden menyatakan tidak pernah membaca majalah. Hal ini memperkuat hipotesis peneliti mengenai mulai ditinggalkannya media-media konvensional sebagai pilihan platform bagi masyarakat dalam memperoleh informasi. Namun televisi tetap menjadi media yang paling banyak dan paling sering dikonsumsi oleh responden. Data pada diagram 2 juga menunjukkan data yang menarik bagaimana frekuensi responden menggunakan media youtube. Sebanyak 
43,7\% responden menyatakan selalu menonton youtube dalam setiap minggunya, namun data juga menunjukkan 33,4\% responden tidak pernah mengkonsumsi youtube sama sekali. Hal ini menunjukkan bahwa ada perilaku yang sangat berbeda pada pola konsumsi youtube. Hasil tabulasi silang menyatakan yang selalu menggunakan youtube adalah yang berusia muda, sedangkan untuk usia yang lebih tua lebih jarang bahkan tidak pernah mengkonsumsi youtube per minggunya.

\section{Masyarakat dan Media Informasi Kebencanaan}

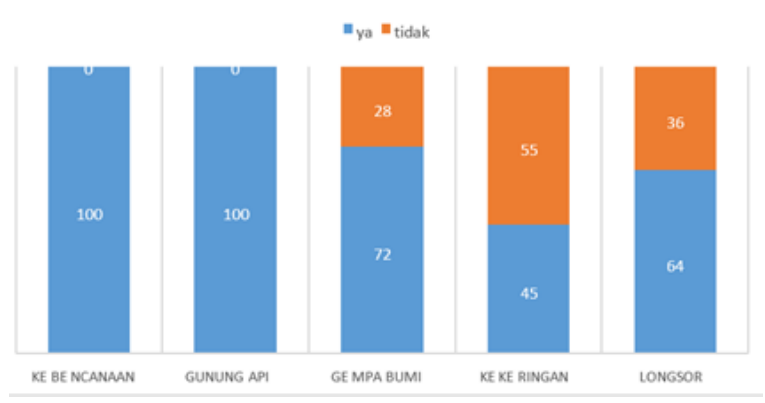

Diagram 3.

\section{Pernah Mendapatkan Informasi Mengenai} Kebencanaan

Pada Diagram 3, digambarkan informasi kebencanaan apa yang kerap dan pernah diterima oleh responden. Dalam penelitian kali ini, peneliti secara khusus meneliti mengenai informasi kebencanaan yang sering diterima oleh masyarakat. Informasi kebencanaan yang dimaksud ialah bencana alam yang membutuhkan kecepatan dalam proses penyebarannya. Untuk mempermudah proses penelitian, peneliti membagi informasi kebencanaan ke dalam 5 jenis bencana alam. Jenis-jenis tersebut antara lain adalah kebencanaan pada umumnya, bencana gunung api, bencana gempa bumi, bencana kekeringan dan bencana tanah longsor. Kelima jenis informasi kebencanaan tersebut memiliki hasil dengan jumlah yang berbedabeda. Dari jumlah total $100 \%$, rata-rata responden yang pernah mendapatkan pengetahuan mengenai kebencanaan. Informasi pengetahuan tentang kebencanaan terbanyak yang sering diterima oleh responden ialah informasi kebencanaan dan gunung api. Jumlah informasi pengetahuan tentang kebencanaan terendah yang diterima oleh responden ialah informasi mengenai kekeringan. Berikut adalah rincian persentase responden dalam menerima informasi pengetahuan tentang kebencanaan. Pengetahuan kebencanaan sebanyak $100 \%$, informasi gunung api sebanyak $100 \%$, informasi gempa bumi sebanyak 72\%, informasi kekeringan sebanyak $45 \%$ dan informasi longsor sebanyak 64\%. Hasil yang beragam tersebut dipengaruhi oleh keadaan lingkungan dan struktur tanah yang berbeda dari masing-masing kabupaten yang menjadi tempat tinggal responden. Selain itu, akses dan sumber informasi bagi responden yang beragam juga turut mempengaruhi dalam penyebaran informasi mengenai kebencanaan. Secara garis besar, akan sangat berbeda hasilnya jika responden yang berdomisili di Kabupaten Bangli dan responden yang berdomisili di Kota Denpasar dalam menjawab pertanyaan penelitian mengenai bencana longsor. Selain karena lingkungan dan geologi yang berbeda, dalam hal ini Kabupaten Bangli berada di dataran tinggi, sedangkan Kota Denpasar berada di dataran rendah, akses informasi yang terbatas bagi wilayah Kabupaten Bangli dibanding kota Denpasar juga menjadi penyebab beragamnya hasil dari penelitian kali ini. Namun dibandingkan

Semua jenis bencana alam, informasi mengenai bencana gunung api adalah informasi yang pernah diterima seluruh responden. Hal ini menunjukkan bencana Gunung Api adalah bencana yang mendapat perhatian bagi responden maupun sumber penyebar informasi kebencanaan.

Hal tersebut berkaitan pula dengan sumber informasi kebencanaan yang bisa digunakan oleh masyarakat di Bali. Pada diagram berikut adalah diagram 4 yang menggambarkan sumber informasi kebencanaan apa yang paling sering digunakan untuk mendapatkan informasi mengenai kebencanaan.

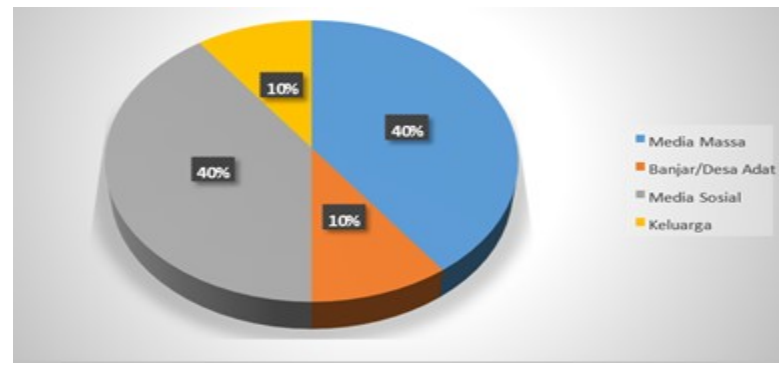

Diagram 4.

\section{Sumber Informasi Kebencanaan}

Dalam penelitian kali ini, peneliti membagi sumber informasi kebencanaan menjadi 4 sumber, yaitu media massa, banjar/desa adat, media sosial dan keluarga. 
Dari data yang didapatkan di lapangan, peneliti mendapatkan hasil yang cukup menarik. Persentase media massa dan media sosial yang dijadikan sumber informasi kebencanaan berada pada besaran yang sama. Hal ini dibuktikan dari jumlah persentase yang cukup tinggi dari kedua sumber informasi tersebut yang masing-masing mendapatkan jumlah presentase sebanyak $40 \%$. Hal ini menunjukkan masyarakat di Bali cukup banyak terterpa informasi kebencanaan dari media massa dan media sosial. Sumber informasi lainnya yang juga menjadi sumber informasi kebencanaan adalah keluarga dan banjar/desa adat. Kedua sumber ini mendapatkan persentase yang cukup rendah dengan hanya $10 \%$. Hal ini menunjukkan bahwa informasi kebencanaan lebih banyak responden terima dari media massa dan media sosial dibandingkan informasi yang bersifat antar pribadi atau kelompok.

\section{Sumber Informasi Aktivitas Gunung Agung}

Informasi kebencanaan kemudian dikerucutkan mengenai informasi kebencanaan yang terkait dengan aktivitas Gunung Agung. Hasil yang peneliti dapatkan juga cukup beragam. Peneliti membagi media referensi yang digunakan responden untuk mengetahui informasi tentang aktivitas Gunung Agung menjadi empat media referensi, yaitu media sosial, media massa, keluarga dan banjar/desa adat. Pertanyaan ini tumbuh disebabkan tren yang menunjukkan bahwa media sosial lebih sering diakses oleh masyarakat dibandingkan media lainnya. Hal lain dikarenakan akses informasi berbasis internet dan digital yang semakin meluas dengan cepat. Data menunjukkan bahwa media dengan jumlah terbanyak sebagai media referensi tentang informasi aktivitas Gunung Agung yang banyak digunakan oleh responden ialah media sosial. Media sosial mendapat hasil persentase sebanyak 42\%. Angka ini lebih tinggi 2\% dari pada media massa yang mendapatkan jumlah presentase sebanyak 40\%. Data ini menunjukkan bahwa media massa seperti televisi, radio, koran dan lain sebagainya menjadi pilihan kedua bagi masyarakat di Bali untuk dijadikan media referensi tentang Gunung Agung. keluarga dan banjar/desa adat juga menjadi media referensi tentang Gunung Agung walaupun dua saluran informasi lainnya mendapatkan persentase yang lebih

rendah. Sebanyak $11 \%$ responden menyatakan keluarga adalah sebagai salah satu media referensi tentang informasi aktivitas Gunung Agung, dan terdapat hanya sebanyak $7 \%$ responden yang menyatakan banjar/desa adat dapat dijadikan media referensi tentang informasi aktivitas Gunung Agung. Hal ini menunjukkan bahwa mereka lebih banyak menggunakan media massa dan media sosial sebagai rujukan untuk mengetahui informasi terkini mengenai aktivitas Gunung Agung.

\section{Dampak Bencana Erupsi Gunung Agung}

Erupsi Gunung Agung yang aktif kembali sejak akhir tahun 2017 lalu tentunya memberi dampak yang signifikan di segala aspek. Dampak riil yang biasa terjadi akibat gunung berapi antara lain adalah hujan abu, hujan pasir, gempa bumi, gemuruh dan juga lahar dingin. Dari kelima dampak alam yang terjadi, hanya hujan abu, gempa bumi dan gemuruh yang bisa dirasakan oleh responden. Sedangkan hujan pasir dan lahar dingin tidak dirasakan oleh para responden.

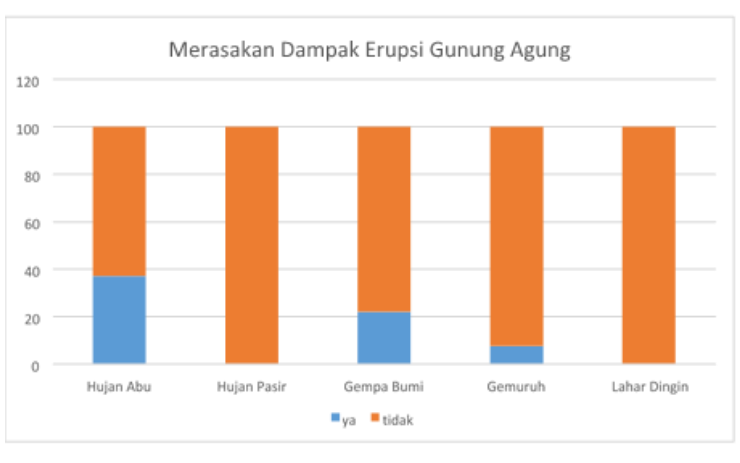

\section{Diagram 5.}

\section{Dampak Erupsi}

Dari diagram 5 di atas diketahui sebanyak kurang lebih 38\% responden menyatakan merasakan dampak erupsi Gunung Agung berupa hujan abu, sedangkan sebanyak kurang lebih 22\% responden menyatakan merasakan dampak erupsi Gunung Agung berupa gempa bumi. Dan yang terendah yakni sebanyak kurang lebih $8 \%$ responden menyatakan merasakan dampak aktivitas Gunung Agung berupa gemuruh. Dari diagram 5. di atas juga diketahui secara umum hampir seluruh responden tidak merasakan dampak langsung dari aktivitas Gunung Agung. Hujan abu pun hanya dialami oleh responden yang berada di Kabupaten Karangasem dan sekitarnya. Namun ironisnya setengah dari responden menyatakan terancam dengan aktivitas 
Gunung Agung. Hal ini terlihat pada diagram 6 di bawah ini.

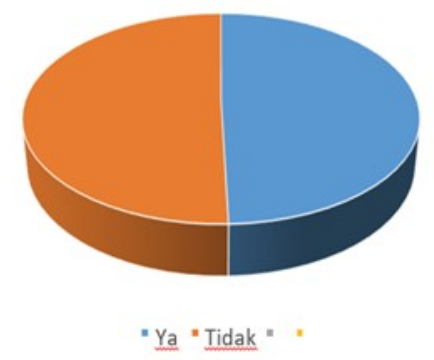

Diagram 6.

Merasa Terancam dengan Gunung Agung

Status Gunung Agung yang dapat berubah sewaktu -waktu tentu sedikit banyak memberikan kekhawatiran bagi masyarakat di Bali. Namun kekhawatiran tersebut justru menumbuhkan sikap waspada dan awas terhadap kondisi gunung agung terkini. Dari data yang peneliti dapatkan, jumlah masyarakat yang merasa terancam dan tidak terancam terhadap status Gunung Agung adalah sama. Sebanyak 50\% responden menyatakan tidak terancam terhadap status terkini Gunung Agung, sedangkan $50 \%$ lainnya menyatakan terancam terhadap status terkini Gunung Agung. Kekhawatiran masyarakat terhadap status terkini Gunung Agung mendorong mereka untuk aktif memantau situasi terkini gunung agung melalui berbagai media dan platform informasi. Hal ini tergambarkan pada diagram 7 mengenai apakah responden memantau status dan aktivitas Gunung Agung. Pada diagram 7 tergambarkan sebanyak 53\% responden menyatakan selalu memantau kondisi terkini dari Gunung Agung. Sementara itu terdapat sebanyak $47 \%$ responden menyatakan tidak memantau Gunung Agung secara intens.

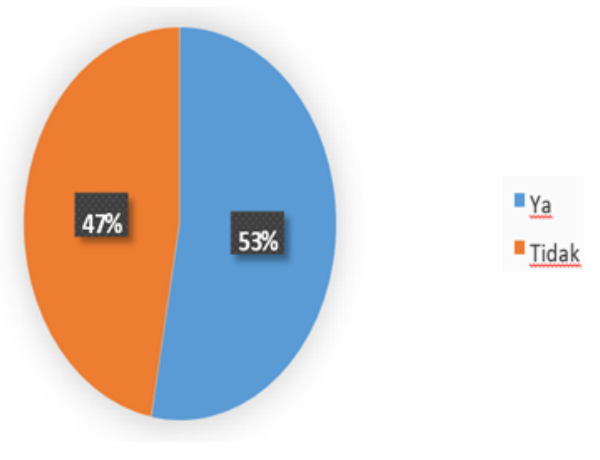

Diagram 7.

Apakah Memantau Status/Aktivitas

Gunung Agung
Media untuk memantau kondisi terkini Gunung Agung cukup beragam. Masyarakat dapat memilih platform yang mudah untuk diakses guna mendapatkan informasi terbaru mengenai status dan aktivitas Gunung Agung. Tidak hanya terus menerus mengandalkan media sosial, namun masyarakat juga menggunakan media masa serta kerabat atau keluarga sebagai media untuk mendapatkan informasi. Tidak bisa dipungkiri, bahwa kekuatan media sosial yang terdepan dalam kecepatan akses informasi menjadi pilihan utama bagi masyarakat untuk "cepat tahu" status Gunung Agung. Hal tersebut dibuktikan dari jumlah responden yakni sebanyak $54 \%$ menyatakan menggunakan media sosial untuk memantau kondisi Gunung Agung. Sementara itu, sebanyak $45 \%$ responden menyatakan menggunakan media massa seperti televisi, koran dan radio untuk memantau status terkini Gunung Agung. Sedangkan hanya sebanyak 1\% responden menyatakan kerabat/keluarga sebagai media untuk memantau status terkini Gunung Agung. Kerabat/keluarga yang dimaksud adalah mereka yang berdomisili di kabupaten Karangasem atau kebupatenkebupaten lainnya yang tergolong dekat dengan lokasi Gunung Agung. Dan atau mereka-mereka yang tinggal di radius kawasan rawan bencana di wilayah Karangasem. Hal ini terlihat pada diagram 8 .

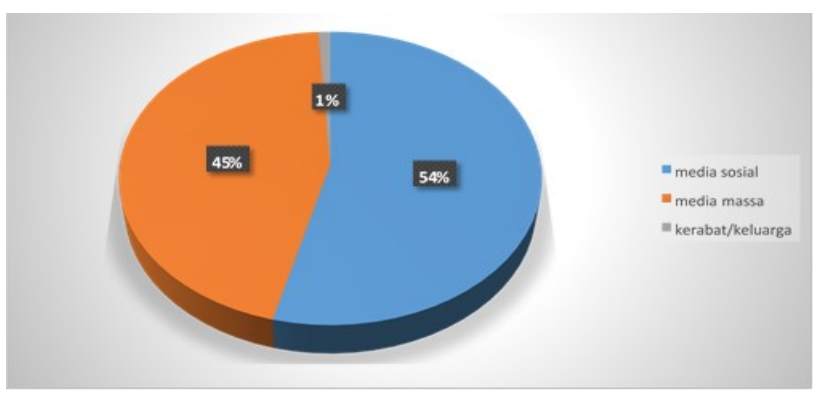

Diagram 8.

Media yang Digunakan dalam Memantau Aktivitas Gunung Agung

Data di atas menunjukkan bahwa media sosial adalah adalah media yang dijadikan rujukan dalam memantau aktivitas Gunung Agung. Hal ini cukup mengkhawatirkan mengingat sifat media sosial yang terkait dengan kredibilitas sumber dan akurasi informasi yang kerap masih dipertanyakan. Sifat informasi yang langsung ke dalam genggaman tanpa ada gatekeeper, dan perasaan terancam dengan aktivitas 
Gunung Agung menyebabkan adanya kepanikan saat ada informasi mengenai naiknya status Gunung Agung dan masyarakat diharapkan untuk segera mengungsi. Kepanikan ini terjadi saat tidak lagi ada kesempatan untuk melakukan verifikasi informasi yang diterima. Data penelitian menunjukkan bahwa hanya sebagian kecil responden yang memiliki kebiasaan untuk memverifikasi informasi yang diterima di media sosial mengenai status dan aktivitas Gunung Agung. Selengkapnya pada diagram 9.

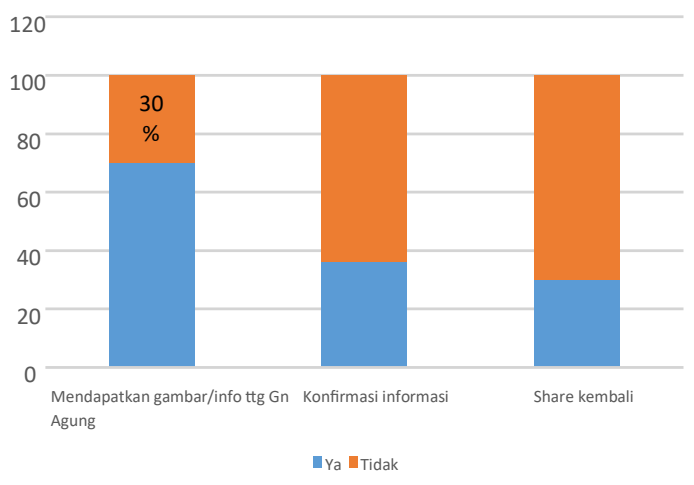

Diagram 9.

Apa yang Dilakukan

Setelah Menerima Info Gunung Agung

Diagram 9 di atas menggambarkan bagaimana respons masyarakat saat menerima informasi berupa teks dan gambar mengenai keadaan Gunung Agung. Sebagian besar responden yakni $70 \%$ responden menyatakan pernah mendapatkan/menerima gambar/ info mengenai Gunung Agung. Namun setelah menerima informasi tersebut hanya $36 \%$ responden yang melakukan konfirmasi informasi atau foto tersebut. Dari diagram 9 diketahui juga bahwa dari yang menerima gambar 30 persennya langsung membagikan kembali. Hal ini menunjukkan bahwa terdapat $30 \%$ responden yang menerima gambar dan langsung membagikan kembali informasi/gambar yang diterima. Responden yang melakukan konfirmasi memilih konfirmasi melalui media massa dan pemerintah.

\section{DISKUSI}

Dari temuan di atas maka diketahui bahwa masyarakat Bali memiliki ketergantungan yang tinggi pada media khususnya untuk mencari dan mengkonsumsi informasi mengenai perkembangan aktivitas Gunung Agung.
Televisi dan media sosial menjadi sumber informasi akan aktivitas Gunung Agung. Berdasarkan teori dependensi, masyarakat di Bali sebenarnya telah memiliki sumber utama maupun sumber media alternatif. Namun sumber utama informasi yang didapatkan adalah dari media sosial seperti whatsapp dan facebook. Bahkan $54 \%$ responden memantau melalui media sosial. Angka ini menunjukkan ketergantungan yang tinggi akan media sosial. Tingkat kepercayaan responden pada media sosial pun tinggi sehingga mempengaruhi responden hingga tingkat afektif dan perilaku.

Dari data di atas juga diketahui bahwa walaupun terdapat alternatif lain untuk mengetahui perkembangan aktivitas Gunung Agung, responden kerap kali membagikan informasi yang ia terima di media sosial tanpa melakukan verifikasi ke media alternatif lainnya.

\section{KESIMPULAN}

Masyarakat di Bali tercatat telah mendapat terpaan mengenai informasi bencana secara luas. Sumber informasi mengenai kebencanaan yang paling banyak digunakan adalah dari media sosial. Namun literasi digital kebencanaan masyarakat masih kurang. Dari data yang diperoleh di atas maka memberi gambaran bahwa sebagian besar masyarakat di Bali tidak cukup memiliki literasi digital kebencanaan. Hal ini ditunjukkan dengan rendahnya masyarakat yang melakukan verifikasi atau konfirmasi atas informasi kebencanaan yang diterimanya. Ironisnya masyarakat pun cenderung membagikan kembali informasi kebencanaan Gunung Agung tanpa melakukan verifikasi.

Hal ini menyebabkan walau pun sebagian besar masyarakat tidak berada di kawasan bencana Gunung Agung namun mereka tetap merasakan terancam. Jadi kegelisahan dan perasaan tidak aman yang mereka rasakan lebih banyak disebabkan dari banyaknya informasi mengenai gunung Agung yang beredar di media sosial mereka. Hal ini diperparah dengan cepatnya informasi mengenai Gunung Agung yang beredar di media sosial tanpa informasi dan terverifikasi.

Saran dari hasil penelitian ini adalah perlunya peningkatan literasi digital dalam konteks kebencanaan bagi masyarakat di Bali. Penelitian ini menambahkan konteks pesan yang harus dimiliki berbagai lembaga 
yang terlibat dalam sistem komunikasi kebencanaan. Lestari dkk (2019) dalam menyusun rencana komunikasi kebencanaan melibatkan berbagai sistem sosial dari berbagai lembaga mulai dari Kepolisian, URC BPBD, PVMBG, Kominfo, Rumah Sakit Daerah, TNI (Lestari, Paripurno, \& Nugroho, 2019). Konteks yang dimaksud adalah pentingnya satu pesan yang seragam untuk beredar di masyarakat. Pesan yang disampaikan selain seragam juga diharapkan dapat secepatnya beredar di masyarakat untuk menangkal misinformasi.

Saran lain yang dapat disampaikan dari penelitian ini adalah penggunaan saluran-saluran informasi berbasis kearifan lokal seperti institusi sosial banjar di Bali. Dalam penelitian terungkap bagaimana banjar dijadikan salah satu tempat memverifikasi informasi mengenai kebencanaan. Fatanti dkk (2019) dalam jurnalnya menekankan bagaimana manajemen kebencanaan di Indonesia masih didominasi analisis saintifik dan meminggirkan pengetahuan dan kearifan lokal. Noer Fatanti (2015) menyatakan bahwa masyarakat di berbagai belahan Indonesia memiliki beragam warisan pengetahuan/ nilai lokal terkait kesiapsiagaan bencana. Oleh karena itu media maupun saluran alternatif-alternatif yang berbasis kearifan lokal menjadi salah satu media yang membantu penyebaran informasi dan berfungsi menangkal informasi bohong yang beredar di media sosial. Ke depannya penelitian dapat dikembangkan menjadi lebih mendalam dengan melihat bagaimana pengaruh informasi kebencanaan di media sosial terhadap sikap dan tindakan masyarakat tidak hanya persepsi dan dampak afektifnya saja.

\section{DAFTAR PUSTAKA}

ATR-BPN.go id. (2019) sumber: http://tataruang.atrbpn.go.id/Bulletin/upload/data_artikel/posisi\%

20indonesia.pdf diakses pada 1 September 2019

Arif, Ahmad. (2010). Jurnalisme Bencana, Bencana Jurnalisme. Pustaka Gramedia : Jakarta

Asteria, Donna. (2016). Optimalisasi Komunikasi Bencana di Media Massa sebagai Pendukung Manajemen Bencana. Jurnal Komunikasi Ikatan Sarjana Komunikasi Indonesia. 01 (2016) 1-11

Budi HH, Setio. (2012). Komunikasi Bencana: Aspek Sistem (Koordinasi, Informasi dan Kerjasama). Jurnal
Komunikasi, Vol.1 No.4. Januari 2012, hal 363-372

Gillmor, Dan. (2006). We The Media, Grassroots Journalism from The People by the People. O'Reilly Media Inc., Cambridge, MA.

Haddow, George D., Kim. S. Haddow. (2008). Disaster Communication in a Changing Media World. Elsevier: USA

Haddow, George D., Kim. S. Haddow. (2014). Disaster Communication in a Changing Media World 2nd Ed. Elsevier: USA

Kompas.com. (2018). dengan judul "Meletus Pertama pada 1808, Ini Catatan Letusan Gunung Agung” sumber: https://regional.kompas.com/ read/2018/07/03/16410061/meletus-pertama-pada1808-ini-catatan-letusan-gunung-agung?page=all diakses pada 31 Agustus 2019

Lestari, P., Paripurno, E. T., \& Nugroho, A. R. B. (2019). Table Top Exercise Disaster Communication Model in Reducing Disaster Risk. Jurnal Penelitian Komunikasi, 22(1), 17-30. https://doi.org/10.20422/ jpk.v22i1.587

Littlejohn, Stephen, Karen Foss. (2009) The Encyclopedia of Communication Theory. Sage Publications : USA

N. Fithryani, (2015). Peran Citizen Journalism dalam Program Berita Stasiun Televisi (Studi Deskriptif Kualitatif terhadap Situs Liputan6.com pada Program Berita Liputan6 SCTV. Interaksi: Jurnal Ilmu Котиnikasi, Vol 4, no,1 pp 22-31. Januari 2015. https:// doi.org/10.14710/interaksi.4.1.22-31

Martono, Nanang. (2010). Statistika Sosial, Teori dan Aplikasi Program SPSS. Gaya Media: Yogyakarta

Noer Fatanti, Megasar., Dyan Rahmiati, Ika Rizki Yustisia. (2019). Merawat Tradisi Lokal sebagai Strategi Pengurangan Risiko Bencana di Dusun Brau, Jawa Timur Preserving Local Traditions as a Strategy for Disaster Risk Reduction in Brau Village, East Java. IPTEK-KOM Vol. 21 No.1, Juni 2019:75-91

Panuju, R. (2018). Etika Jurnalistik dan Jurnalisme Bencana pada Pemberitaan Gunung Agung di Portal Berita Balipost.com. Jurnal ILMU KOMUNIKASI, 15 
(2), 219-232. https://doi.org/10.24002/jik.v15i2.1455

PEW Reseacrh centre. (2019). "Mobile Fact Sheets" sumber: https://www.pewinternet.org/fact-sheet/mobile/ diakses pada 2 September 2019

Purwo Nugroho, Sutopo., Dyah Sulistyorini. (2018). Komunikasi Bencana, Membedah Relasi BNPB dengan Media. Pusat Data, Informasi dan Hubungan Masyarakat BNPB : Jakarta

R. Yudha. (2017). Tantangan Literasi Era Media Digital (Analisa Pengguna Media Berdasarkan Model Kemungkinan Elaborasi). Interaksi: Jurnal Ilmu Komunikasi vol. 6 no.1 pp. 132-139, Dec. 2017.https:// doi.org/10.14710/interaksi.6.1.132-139

Rudianto. (2015). Komunikasi dalam Penanggulangan Bencana. Jurnal Simbolika, 1(1), 1-12. https:// doi.org/10.1139/T08-100

Trisnani. (2019). “Whatsapp sebagai Media Komunikasi Tokoh Masyarakat”, Media Digital dan Perubahan Budaya Komunikasi, Arifianto S., (ed). Balitbang Kominfo \& Aswaja Presindo : Yogyakarta

UU No 24 Tahun 2007 tentang Penanggulangan Bencana 